\section{MERANCANG RPP \\ INOVATIF DALAM \\ PROGRAM MERDEKA \\ BELAJAR \\ PADA MGMP IPS SMP SE- KABUPATEN JEMBER}

Sri Kantun', Dwi Herlindawati ${ }^{2}$, Lisana

Oktavisanti $\mathrm{M}^{3}$

I,2,3 Universitas Jember

* Sri Kantun

Email : srikantun.fkip@unej.ac.id

\begin{abstract}
The design of the RPP in the "Merdeka Belajar" program simplifies the making of lesson plans on one sheet. The three core components of the lesson plan are learning objectives, learning activities, and assessments. Therefore, it is necessary to immediately take concrete and innovative steps be able to produce an innovative RPP that can implement the true and complete "Merdeka Belajar" program. The purpose of this activity is to provide an understanding of the design of the lesson plans in the "Merdeka Belajar" program, by chang the technique of preparing the lesson plans which so far have been made in sheets into one sheet. The method in this activity is the lecture method and online demonstration. Community Service Activities with the theme Designing Innovative Lesson Plans in the Independent Learning Program at the Social Studies MGMP of Junior High Schools in Jember Regency had a positive impact. Social Studies teachers have become more aware of the Innovative RPP for independent learning launched by the Minister of Education and Culture.
\end{abstract}

Keywords: RPP Inovatif, Program Merdeka Belajar, IPS

\begin{abstract}
Abstrak
Rancangan Rencana Pelaksanaan Pembelajaran (RPP) dalam program “Merdeka Belajar" menyederhanakan pembuatan RPP pada satu lembar. Tiga komponen inti pada RPP tersebut yaitu Tujuan pembelajaran, Kegiatan pembelajaran, dan Asesmen. Oleh karena itu diperlukan segera langkah nyata dan inovatif untuk dapat menghasilkan Rencana Pelaksanaan Pembelajaran (RPP) inovatif yang dapat mengimplementasikan program "Merdeka Belajar" yang sebenarnya dan seutuhnya. Adapun tujuan dari kegiatan ini adalah untuk memberikan pemahaman tentang desain rancangan RPP dalam program “Merdeka Belajar, dengan merubah teknik penyusunan RPP yang selama ini telah dibuat berlembar-lembar menjadi satu lembar. Metode dalam kegiatan ini dengan metode ceramah dan demonstrasi secara online. Kegiatan Pengabdian Kepada Masyarakat dengan tema Merancang RPP Inovatif dalam Program Merdeka Belajar Pada MGMP IPS SMP SeKabupaten Jember memiliki dampak positif. Guru-guru IPS menjadi lebih paham tentang RPP Inovatif dalam merdeka belajar yang dicanangkan oleh Mendikbud.
\end{abstract}

Kata Kunci: RPP Inovatif, Program Merdeka Belajar, IPS

Received: August 02, 202 I / Accepted: August 03, 202 I / Published Online: August 10, 2021 
Merancang RPP Inovatif dalam Program Merdeka Belajar pada MGMP IPS SMP Se-Kabupaten Jember

Sri Kantun, Dwi Herlindawati, Lisana Oktavisanti M

Vol. 1, No. 2, Agustus 2021 hal. 137-146

DOI Artikel : 10.46306/jub.v1i2.29

\section{PENDAHULUAN}

Saat ini bidang pendidikan di Indonesia bergerak mengalami perubahan-perubahan yang luar biasa. Di bawah kepemimpinan Presiden Joko Widodo, melalui Kementerian Pendidikan dan Kebudayaan (Kemendikbud), yaitu oleh Bapak Nadiem Makarim mulai banyak mengeluarkan kebijakan- kebijakan yang dianggap masyarakat banyak sangat revolusiner. Salah satunya adalah program "Merdeka Belajar" untuk setiap jenjang pendidikan dari sekolah dasar, menengah, atas dan pendidikan tinggi. Ada empat pokok kebijakan pendidikan "Medeka Belajar" yang akan menjadi fokus perubahan yaitu:

(I) Ujian Sekolah Berstandar Nasional (USBN);

(2) Ujian Nasional (UN);

(3) Rencana Pelaksanaan Pembelajaran (RPP);

(4) Peraturan Penerimaan Peserta Didik Baru (PPDB) Zonasi (Kemdikbud, 2019).

Tahun 2020 USBN akan diganti dengan ujian (asesmen) yang diselenggarakan hanya oleh sekolah. Ujian untuk menilai kompetensi siswa dapat dilakukan dalam bentuk tes tertulis dan/atau bentuk penilaian lain yang lebih komprehensif, seperti portofolio dan penugasan., sehingga guru dan sekolah lebih merdeka dalam menilai hasil belajar siswa. Tahun 2020 UN akan dilaksanakan untuk terkahir kalinya, dimana pada tahun 202I UN akan diubah menjadi Asesmen Kompetensi Minimum dan Survey Karakter, yaitu "sebuah penilaian kompetensi pada tingkat yang benarbenar minimum dimana kita bisa memetakan sekolah-sekolah dan daerah-daerah berdasarkan tingkat kompetensi minimum dari daerah tersebut”, kata Menteri Pendidikan dan Kebudayaan Nadiem Makarim dalam peluncuran empat pokok kebijakan pendidikan “Merdeka Belajar', di Jakarta, Rabu (I I/I2/20/9).

Arahan kebijakan baru mengenai PPDB akan diberlakukan kebijakan PPDB lebih fleksibel untuk mengakomodasi ketimpangan dan kualitas di berbagai daerah : Jalur zonasi minima 5\%, Jalur afirmasi minimal I5\%, Jalur perpindahan maksimal 5\%, Jalur prestasi sisanya $0-30 \%$ (disesuaikan dengan kondisi daerah). Dimana daerah berwenang menentukan proporsi final dan menetapkan wilayah zonasi. Untuk pemerataan akses dan kualitas pendidikan perlu diiringi dengan inisiatif lainnya oleh pemerintah daerah, seperti redistribusi guru ke sekolah yang kekurangan guru (Kemendikbud, 2019).

Rencana Pelaksanaan Pembelajaran (RPP) yang merupakan pedoman penting yang harus dimiliki oleh masingmasing guru dalam melaksanakan proses pembelajaran demi tercapainya keberhasilan pembelajaran, juga menjadi fokus perubahan dalam program "Merdeka Belajar" dimana para guru akan diberikan kebebasan untuk dapat memilih, membuat, menggunakan dan mengembangkan format Rencana Pelaksanaan Pembelajaran (RPP). Tiga komponen intipada yang harus ada pada sebuah Rencana Pelaksanaan Pembelajaran (komponen lainnya bersifat pelengkap dan dapat dipilih secara mandiri) yaitu Tujuan pembelajaran, Kegiatan pembelajaran, Asesmen, dan cukup disajikan dengan satu halaman RPP saja. Diharapkan guru dapat menyusun RPP secaran efisien dan efektif sehingga guru memiliki banyak waktu untuk mempersiapkan dan mengevaluasi proses pembelajaran itu sendiri.

Rancangan Rencana Pelaksanaan Pembelajaran (RPP) dalam program "Merdeka Belajar" menyederhanakan pembuatan RPP pada satu lembar saja telah banyak menimbulkan pertanyaan dan keingintahuan yang besar oleh para guru dalam penyusunan RPP tersebut. Dimana kita ketahui bersama selama ini RPP yang disusun dan dipergunakan seluruh guru merupakan rancangan rencana pembelajaran yang dibuatdan dituangkan pada beberapa lembar halaman untuk memuat secara detail rencana pembelajaran. Dengan diarahkannya pada kebijakan baru pada program "Merdeka Belajar" yang hanya membutuhkan satu lembar halaman RPP saja namun telah memuat tiga pokok poin penting yang harus dicantumkan pada RPP tersebut, apakah guru harus mengganti semua RPP yang telah digunakan selama ini dengan format RPP baru yang sesuai program "Merdeka Belajar”. 
Merancang RPP Inovatif dalam Program Merdeka Belajar pada MGMP IPS SMP Se-Kabupaten Jember

Sri Kantun, Dwi Herlindawati, Lisana Oktavisanti M

Vol. 1, No. 2, Agustus 2021 hal. 137-146

DOI Artikel : 10.46306/jub.v1i2.29

Kemdikbud melalui Bapak Menteri menjawab beberapa pertanyaan yang muncul dari perubahan rancangan RPP tersebut, bahwasanya RPP yang telah ada bisa tetap digunakan dan bisa disesuaikan atau dimodifikasi sesuai prinsip efisien, efektif dan berorientasi pada murid. Terkait standar yang ditanyakan Bapak Menteri pun mejawab tidak ada standar khusus, guru bebas membuat, memilih, mengembangkan, dan menggunakan RPP sesuai dengan prinsip efisien, efektif dan berorientasi pada murid. Pak Menteri juga mengemukakan arti tiga prinsip yang digunakan dalam membuat rancangan RPP tersebut yaitu Efisiensi berarti penulisan RPP dilakukan dengan tepat dan tidak menghabiskan banyak waktu dan tenaga; Efektif berart penulisan RPP dilakukan untuk mencapai tujuan pembelajaran; serta Berorientasi pada murid berarti penulisan RPP dilakukan dngan memepertimbangkan kesiapan, ketertarikan, dan kebutuhan belajar murid di kelas (Kemdikbud, 2019).

Berbagai jawaban yang dikemukakan di atas telah mengarahkan pengetahuan kita semua terkait hal-hal teknik dan pelaksanaan perancangan desain Rencana Pelaksanaan Pembelajaran (RPP) ini agar bisa terwujud sesuai dengan yang dicita-citakan pada program "Merdeka Belajar". Seluruh guru di semua jenjang pendidikan di Indonesia diharapkan oleh Bapak Menteri mulai aktif menambah dan memperbanyak pengetahuan serta materiagar dapat mengimplementasikan rancangan desain Rencana Pelaksanaan Pembelajaran (RPP) disajikan cukup pada satu lembar halaman saja yang berorientasi pada prinsip efisien, efektif dan berorientasi pada murid.

Peran Musyawarah Guru Mata Pelajaran (MGMP) sebagai forum/wadah perwakilan kegiatan profesional guru mata pelajaran sejenis di sanggar yang terdiri dari dua unsur yaitu musyawarah dan guru mata pelajaran, dimana musyawarah mencerminkan kegiatan dari, oleh dan untuk guru, sedangkan mata pelajaran adalah guru SMP dan SMA negeri atau swasta yang mengasuh dan bertanggung jawab mengelola mata pelajaran yang ditetapkan di dalam kurikulum (Depdiknas, 1995). Melalui MGMP guru-guru dalam satu pelajaran dapat mendiskusikan berbagai permasalahan serta alternatif pemecahannya yang berkaitan dengan proses serta hasil belajar siswa (Indrawati,2004).

Peran MGMP yang nantinya akan menjadi ujung tombak perwakilan para guru dalam melakukan implemetasi perubahan rancangan Rencana Pelaksanaan Pembelajaran (RPP), denganharapan akanterwujudrancangan RPP inovatif sesuai program "Merdeka Belajar" dengan baik sesuai prinsip yang telah dikemukakan Bapak menteri. Oleh karena itu diperlukan segera langkah nyata dan inovatif untuk dapat menghasilkan Rencana Pelaksanaan Pembelajaran (RPP) inovatif yang dapat mengimplementasikan program "Merdeka Belajar” yang sebenarnya dan seutuhnya.

Guru- guru yang tergabung pada MGMP IPS jenjang Sekolah Menengah Pertama (SMP) di Wilayah Kota Kabupaten Jember juga sudah memulai menggali berbagai informasi dan keilmuan yang sesuai terkait langkah-langkah yang kongkrit dan nyata untuk penyusunan Rancangan Rencana Pelaksanaan Pembelajaran (RPP) sesuai dengan program “Merdeka Belajar”.Keberhasilan langkah-langkah MGMP dalam merancang desain RPP inovatif sesuai dengan prinsip dan cita-cita program "Merdeka Belajar" tentu membutuhkan banyak dukungan dan peran aktif dari berbagai pihak. Salah satunya dapat diberikan workshop atau pelatihan untuk membekali para guru yang tergabung dalam MGMP untuk mendapatkan lebih banyak pengetahuan terkait materi, teknik, dan praktek hingga dapat dihasilkannya sebuah rancangan desaim RPP yang yang inovatif sesuai dengan prinsip program "Merdeka Belajar".

Pengabdian pada masyarakat dalam bentuk workshop ini bertujuan untuk memberikan untuk memberikan gambaran desain rancangan RPP dalam program "Merdeka Belajar, untuk merubah teknik penyusunan RPP yang selama ini telah dibuat berlembar-lembar menjadi satu lembar saja. Rancangan RPP yang dibuat lebih ringkas tentu akan membutuhkan isi materi RPP yang inovatif dan kreatif yang dapat menggambarkan rancangan pembelajaran yang efektif, efisien untuk tercapainya tujuan suatu pembelajaran.

\section{METODE PENGABDIAN}

Kegiatan pengabdian masyarakat ini diselenggarakan pada tanggal 28 November 2020 secara virtual melalui aplikasi Zoom. Hal tersebut dilakukan sesuai anjuran pemerintah untuk melakukan Pembatasan Sosial Berskala Besar (PSBB) dan social distancing untuk mencegah kemungkinan penyebaran virus corona supaya tidak semakin semakin 
Merancang RPP Inovatif dalam Program Merdeka Belajar pada MGMP IPS SMP Se-Kabupaten Jember

Sri Kantun, Dwi Herlindawati, Lisana Oktavisanti M

Vol. 1, No. 2, Agustus 2021 hal. 137-146

DOI Artikel : 10.46306/jub.v1i2.29

meluas. Peserta pengabdian kepada masyarakat ini adalah guru-guru yang anggota Musyawarah Guru Mata Pelajaran (MGMP) mata pelajaran Ilmu Pengetahuan Sosial (IPS) se-Kabupaten Jember sebanyak 55 orang.

Sebelum kegiatan workshop dilaksankan, kami tim pengabdian pada masyarakat melakukan analisis awal yaitu analisis situasi dan kondisi pada guru-guru IPS SMP se Kabupaten Jember sebagai landasan pemilihan materi workshop yang akan diberikan dengan cara diskusi langsung bersama pengurus MGMP IPS Kabupaten Jember. Setelah mendapat persetujuan dari Lembaga Penelitian dan Pengabdian Masyarakat (LP2M) Universitas Jember, maka kegiatan pengabdian yang dilakukan adalah memberikan pelatihan untuk merancang RPP inovatif dalam Program "Merdeka Belajar" pada guru-guru anggota MGMP IPS SMP se Kabupaten Jember. Pelaksaan wokshop online untuk menambah pengetahuan para guru dalam merancang desain RPP inovatif sesuai program "Merdeka Belajar" dilaksanakan dengan memberikan teori dan praktik. Kegiatan Penugasan ini dimaksudkan sebagai solusi terhadap permasalahan yang dihadapi para guru khususnya guru MGMP IPS SMP se-Kabupaten Jember sebagai wadah perwakilan pengasuh dan penanggung jawab mata pelajaran IPS SMP di Kabupaten Jember, agar dapat menyusun rancangan desain RPP yang inovatif dalam program “Merdeka Belajar”. Metode kegiatan pengabdian yang digunakan, antara lain:

a. Ceramah

Metode ceramah secara online dipilih untuk menyampaikan konsep teori tentang membuat rancangan desain RPP inovatif pada program "Merdeka Belajar" secara detail mengenai isi materi, produk RPP inovatif hingga proses evaluasi. Penggunaan metode ceramah online dilakukan secara video teleconference dengan menggunakan aplikasi Google Meet.

b. Demonstrasi

Metode demonstrasi dipilih untuk menunjukkan suatu proses penyusunan rancangan desain RPP inovatif sehingga dapat memberikan kemudahan bagi peserta workshop online. Demonstrasi dilakukan oleh para dosen sebagai narasumber dengan harapan peserta workshop online dapat melaksanakan praktik secara sempurna dalam penyusunan rancangan desain RPP Inovatif dalam program "Merdeka Belajar" sesuai dengan petunjuk yang telah diberikan oleh narasumber.

\section{PELAKSANAAN DAN PEMBAHASAN}

Kegiatan pengabdian pada masyarakat ini bertujuan untuk memberikan bantuan dalam upaya peningkatan dan pengembangan profesionalisme guru IPS SMP se-Kabupaten Jember melalui pembinaan dalam merancang RPP Inovatif dalam merdeka belajar.

Kegiatan pengabdian ini memberikan pengetahuan dan pemahaman kepada guru-guru IPS tentang bagaimana merancang RPP Inovatif dalam merdeka belajar yang telah dicanangkan oleh Menteri Pendidikan dan Kebudayaan. Dalam kegiatan ini terdapat tiga orang pemateri atau narasumber, antara lain:.

\begin{tabular}{|c|l|l|}
\hline No. & \multicolumn{1}{|c|}{ Nama } & \multicolumn{1}{|c|}{ Materi } \\
\hline I. & Dr. Sri Kantun, M.Ed. & $\begin{array}{l}\text { Peningkatan kemampuan guru untuk memahami } \\
\text { materi tentang program Merdeka Belajar dan } \\
\text { RPP Inovatif }\end{array}$ \\
\hline 2. & Dwi Herlindawati, S.Pd., M.Pd. & $\begin{array}{l}\text { Definisi program Merdeka Belajar, } \\
\text { penyederhanaan RPP dan langkah-langkah } \\
\text { menyusun RPP Inovatif }\end{array}$ \\
\hline 3. & $\begin{array}{l}\text { Lisana Oktavisanti .M, S.Pd., } \\
\text { M.Pd. }\end{array}$ & $\begin{array}{l}\text { Manajemen dan efisiensi waktu pengaplikasian } \\
\text { rancangan RPP Inovatif dalam kaitannya dengan } \\
\text { pemanfaatan media pembelajaran berbasis TI/E- } \\
\text { learning yang ada di masing-masing sekolah. }\end{array}$ \\
\hline
\end{tabular}

Berdasarkan evaluasi kami, para peserta sangat antusias dalam mengikuti kegiatan ini. Karena itulah kami berusaha menyajikan materi dengan semenarik mungkin agar suasana tidak menegangkan. Selain itu kami juga 
Merancang RPP Inovatif dalam Program Merdeka Belajar pada MGMP IPS SMP Se-Kabupaten Jember

Sri Kantun, Dwi Herlindawati, Lisana Oktavisanti M

Vol. 1, No. 2, Agustus 2021 hal. 137-146

DOI Artikel : $10.46306 /$ jub.v1i2.29

melakukan pembimbingan penyusunan RPP Inovatif dalam merdeka belajar. Ketika sesi tanya jawab berlangsung, banyak peserta yang ingin berpartisipasi. Akan tetapi, karena keterbatasan waktu, kami membatasi 5 (lima) pertanyaan dari peserta kegiatan ini.

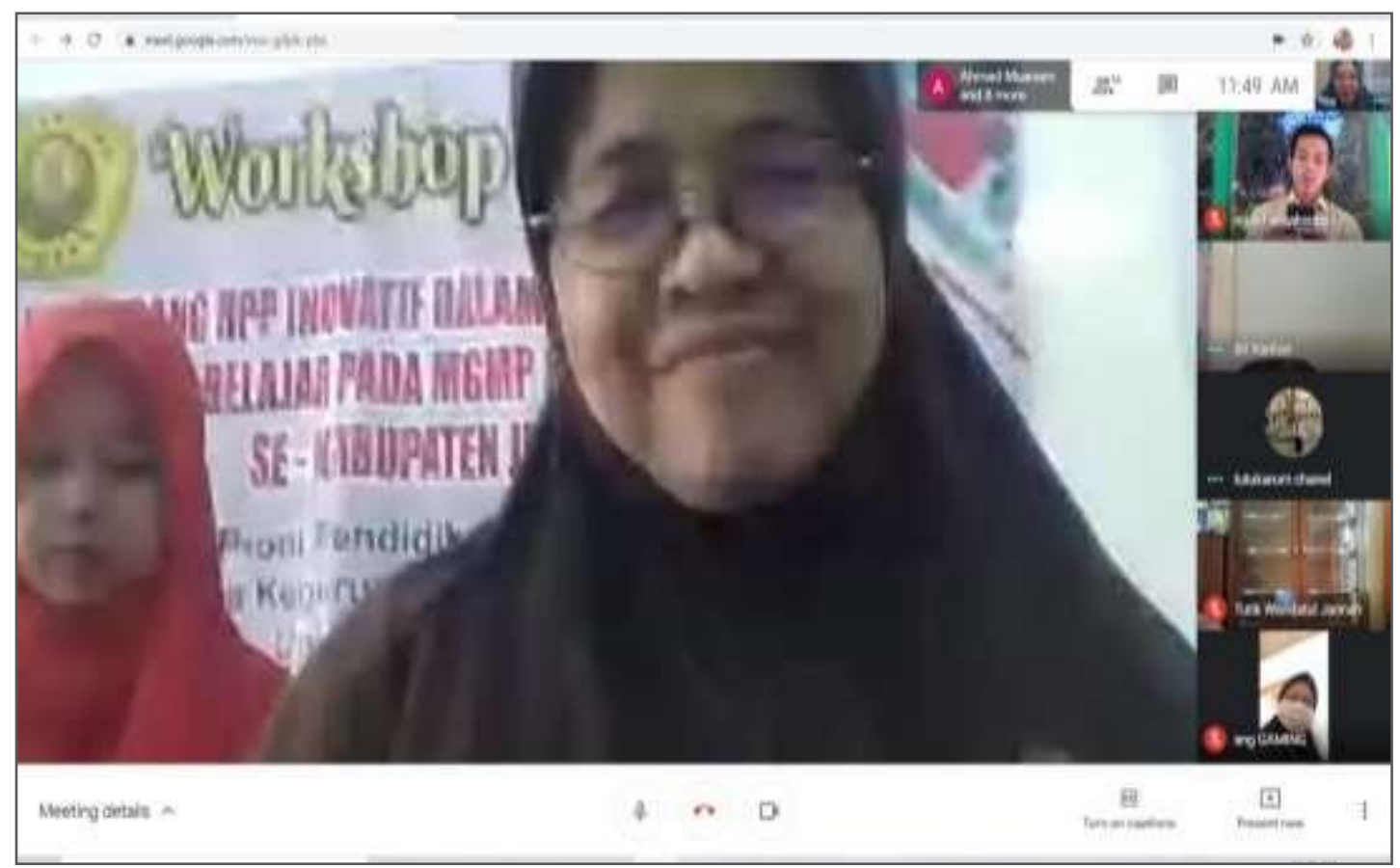

Gambar I. Pembukaan kegiatan Pengabdian Kepada Masyarakat

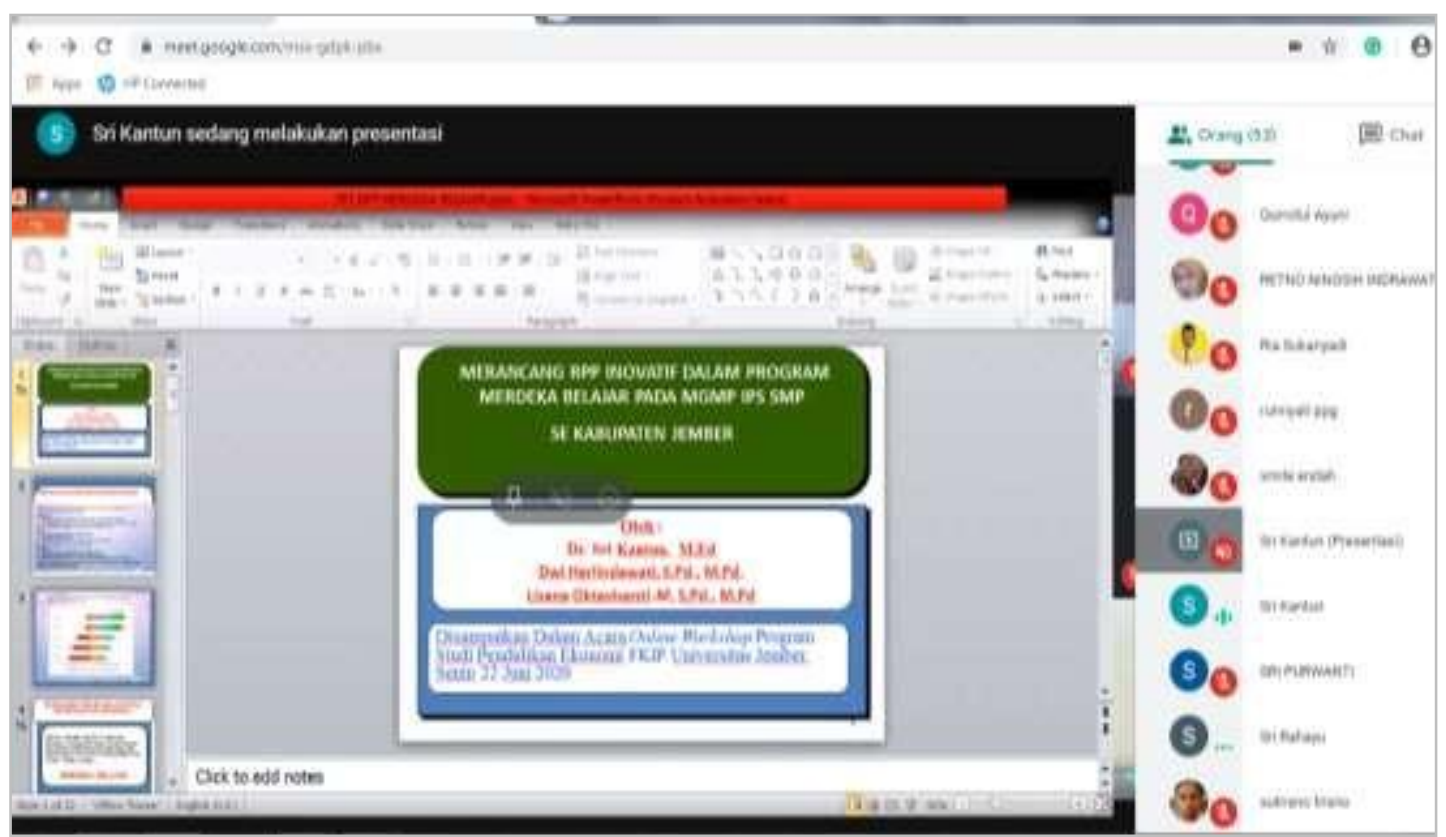

Gambar 2. Pemaparan materi pertama oleh Dr. Sri Kantun, M.Ed. 
Merancang RPP Inovatif dalam Program Merdeka Belajar pada MGMP IPS SMP Se-Kabupaten Jember

Sri Kantun, Dwi Herlindawati, Lisana Oktavisanti M

Vol. 1, No. 2, Agustus 2021 hal. 137-146

DOI Artikel : 10.46306/jub.v1i2.29

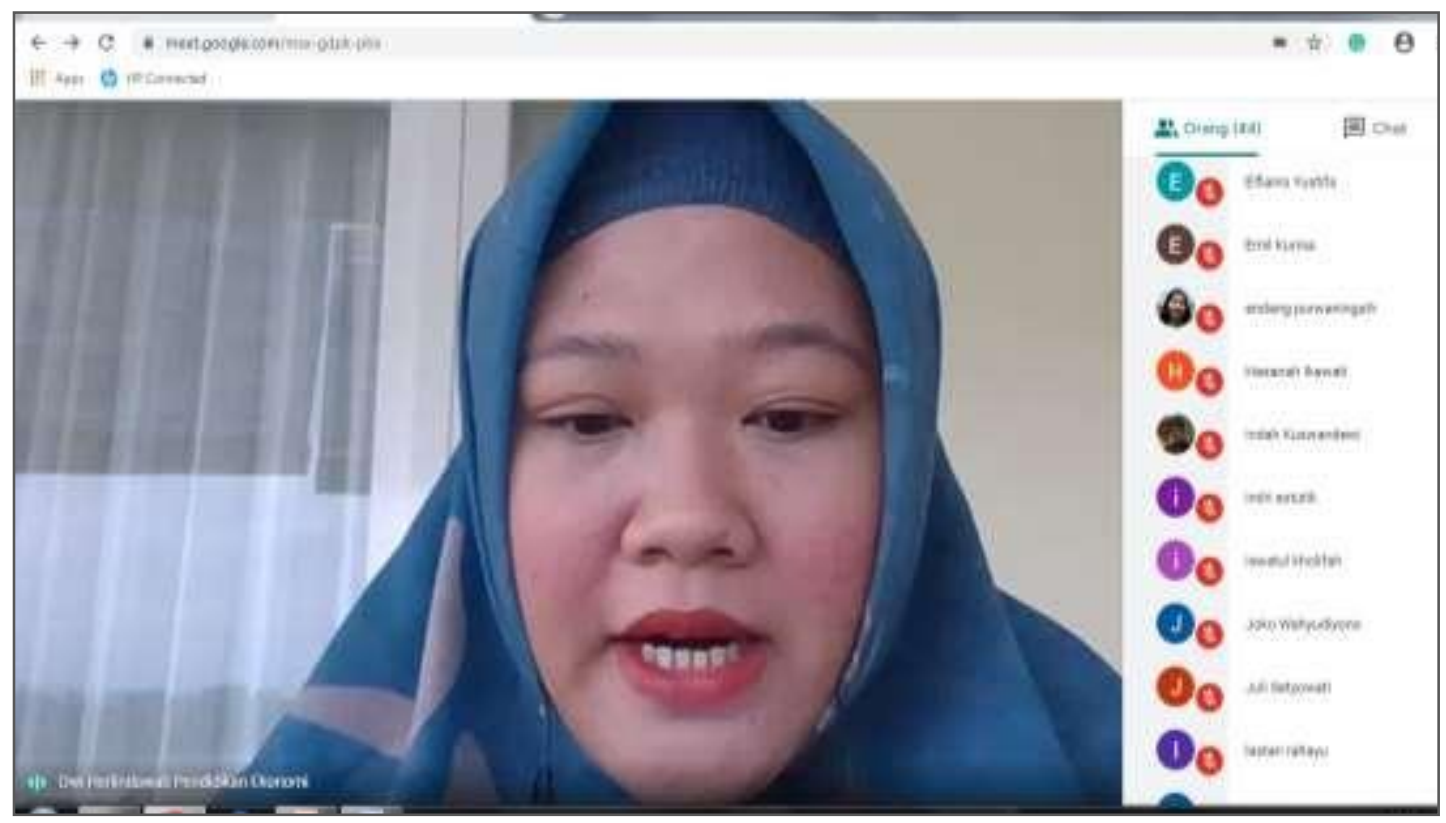

Gambar 3. Pemaparan materi kedua oleh Dwi Herlindawati, S.Pd., M.Pd.

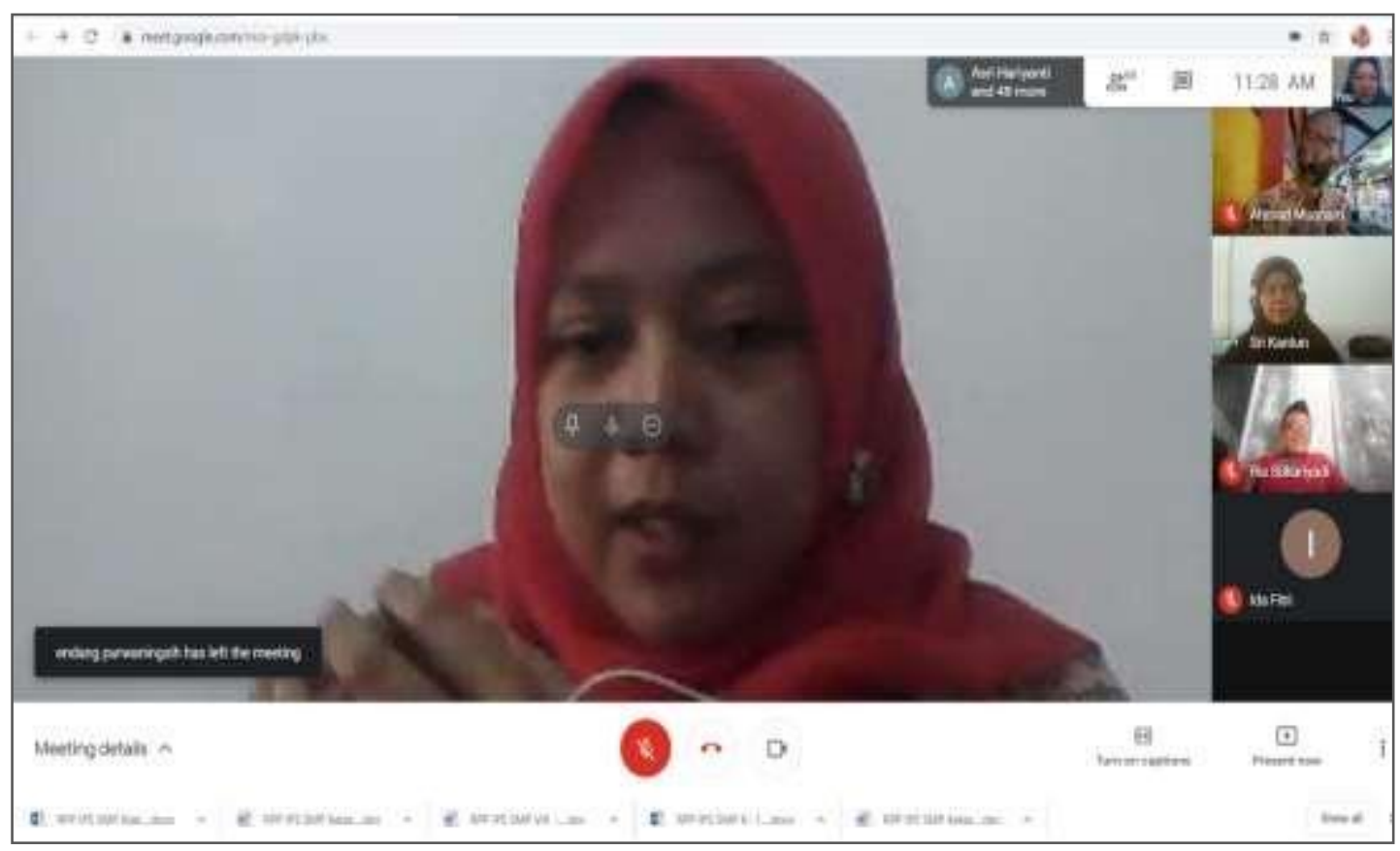

Gambar 4. Pemaparan materi ketiga oleh Lisana Oktavisanti .M, S.Pd., M.Pd. 
Merancang RPP Inovatif dalam Program Merdeka Belajar pada MGMP IPS SMP Se-Kabupaten Jember Sri Kantun, Dwi Herlindawati, Lisana Oktavisanti M

Vol. 1, No. 2, Agustus 2021 hal. 137-146

DOI Artikel : 10.46306/jub.v1i2.29

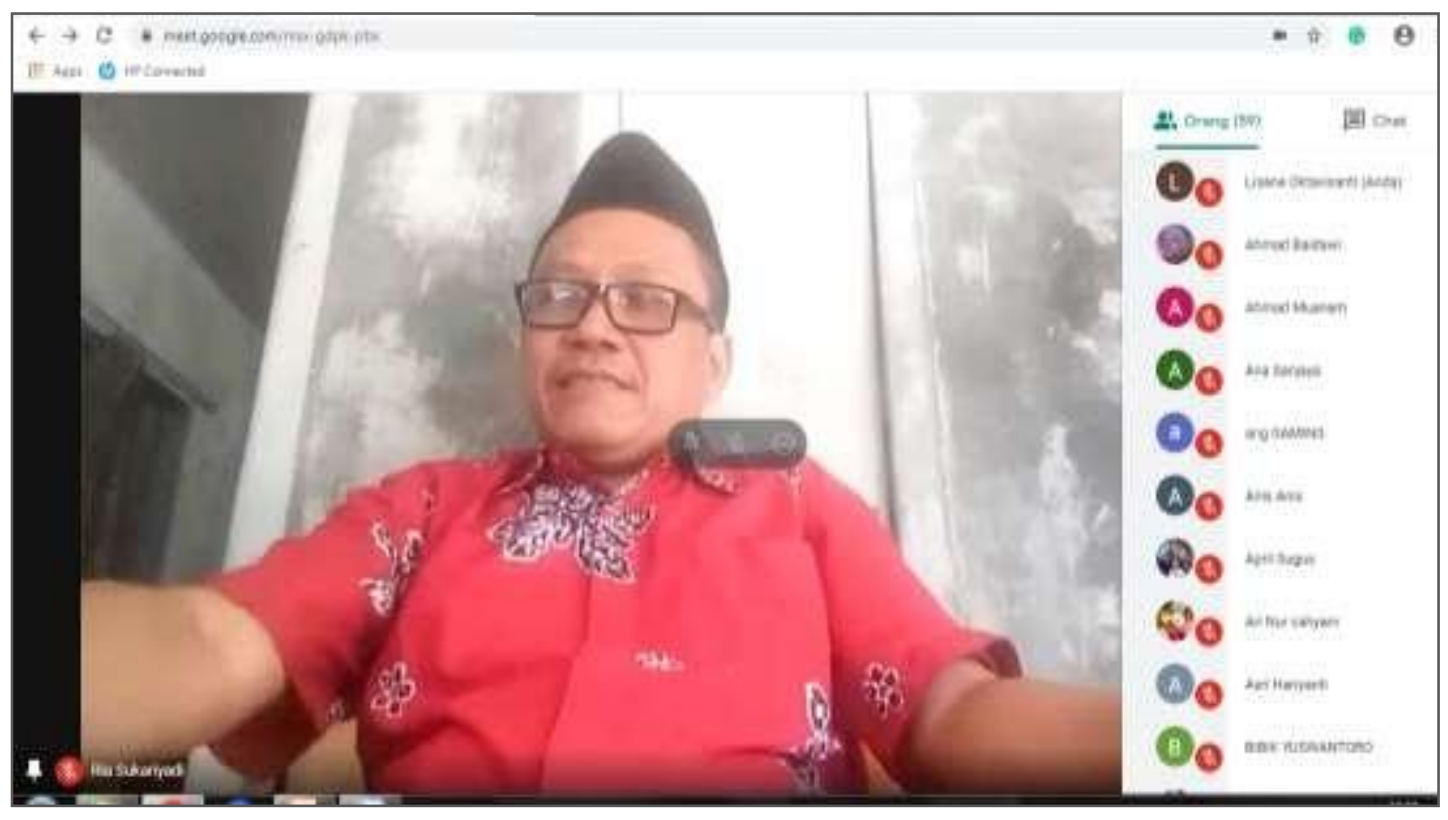

Gambar 5. Peserta pertama sedang menyampaikan pertanyaan

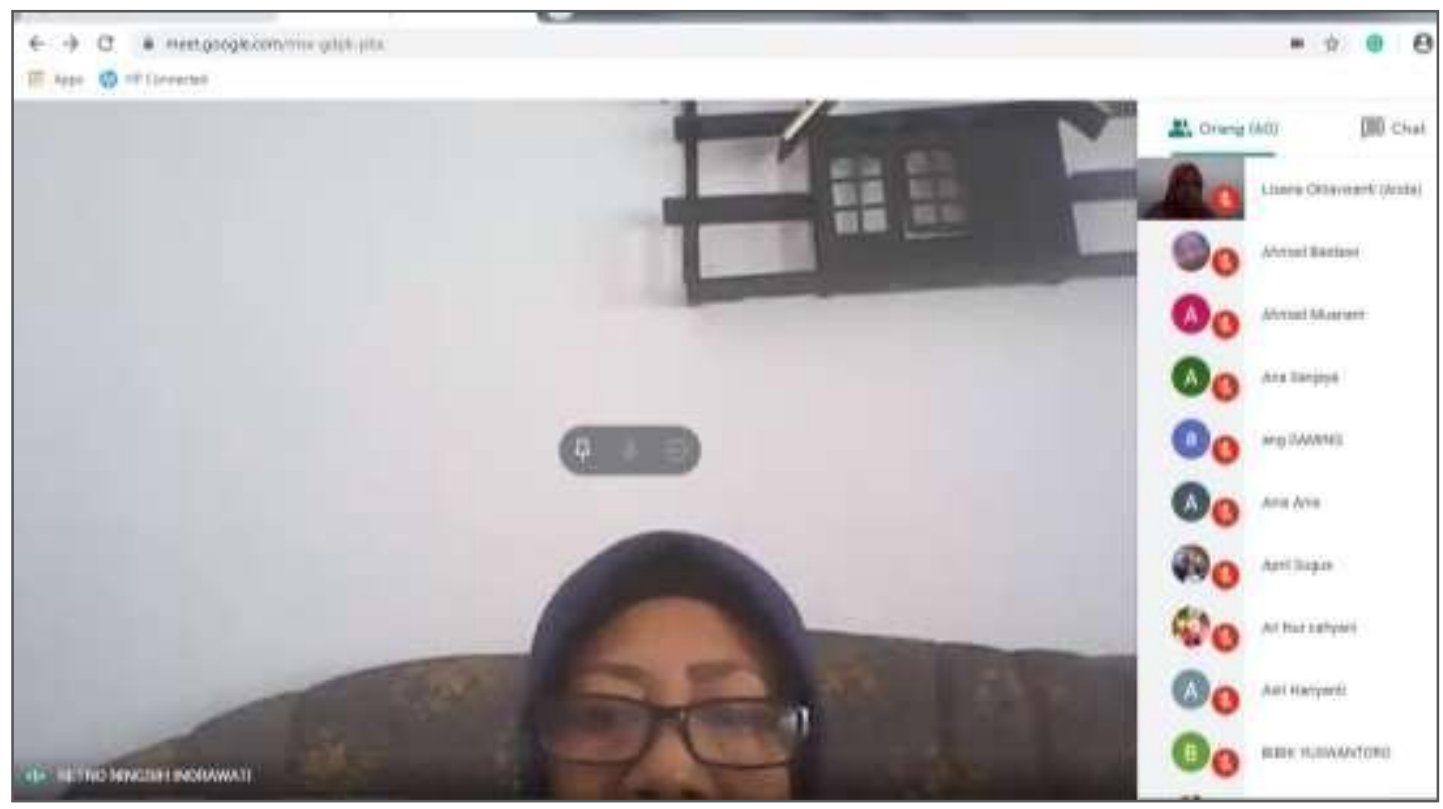

Gambar 6. Peserta kedua sedang mengajukan pertanyaan 
Merancang RPP Inovatif dalam Program Merdeka Belajar pada MGMP IPS SMP Se-Kabupaten Jember

Sri Kantun, Dwi Herlindawati, Lisana Oktavisanti M

Vol. 1, No. 2, Agustus 2021 hal. 137-146

DOI Artikel : 10.46306/jub.v1i2.29

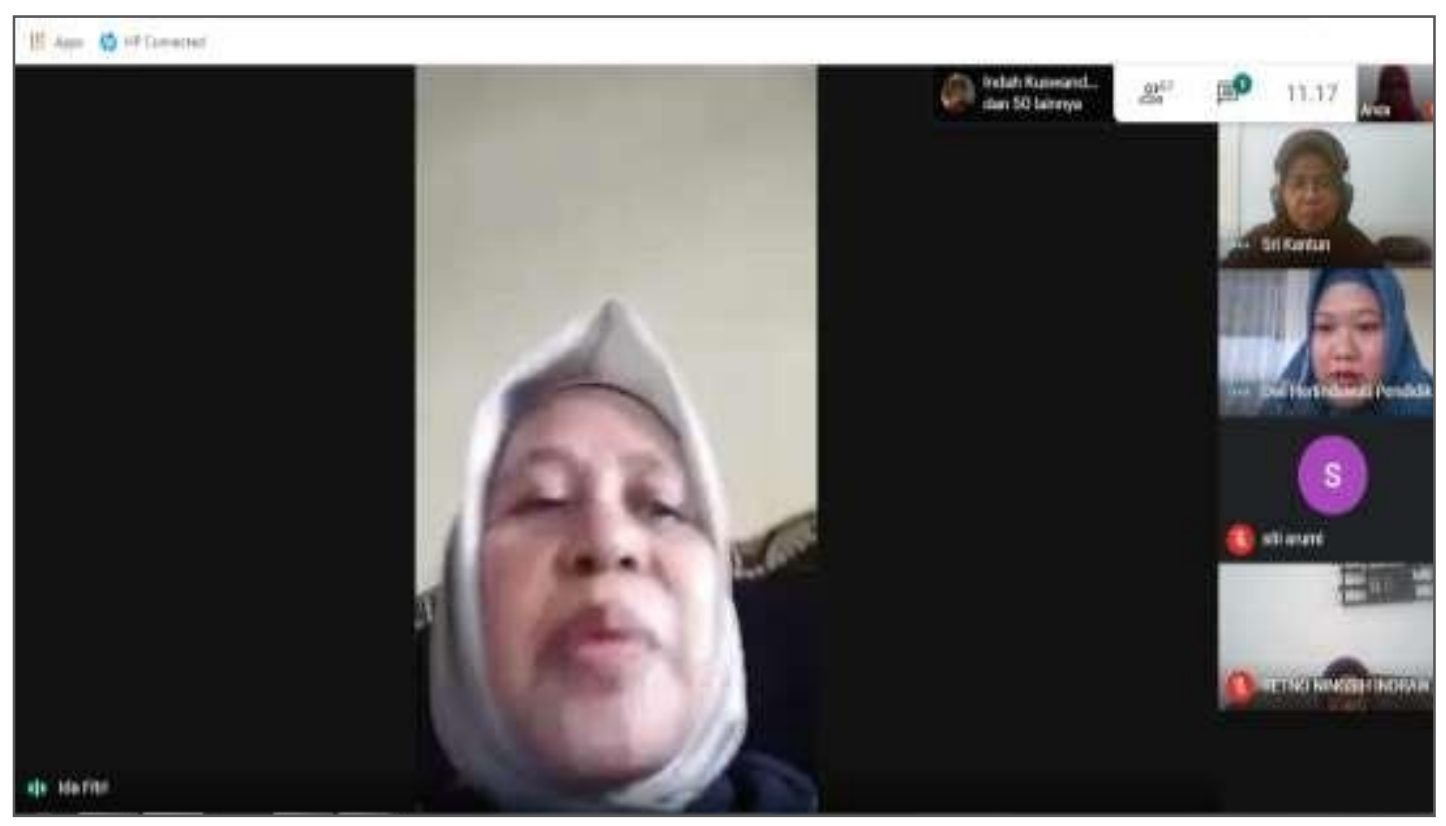

Gambar 7. Pengajuan pertanyaan dari lbu Ida Fitri

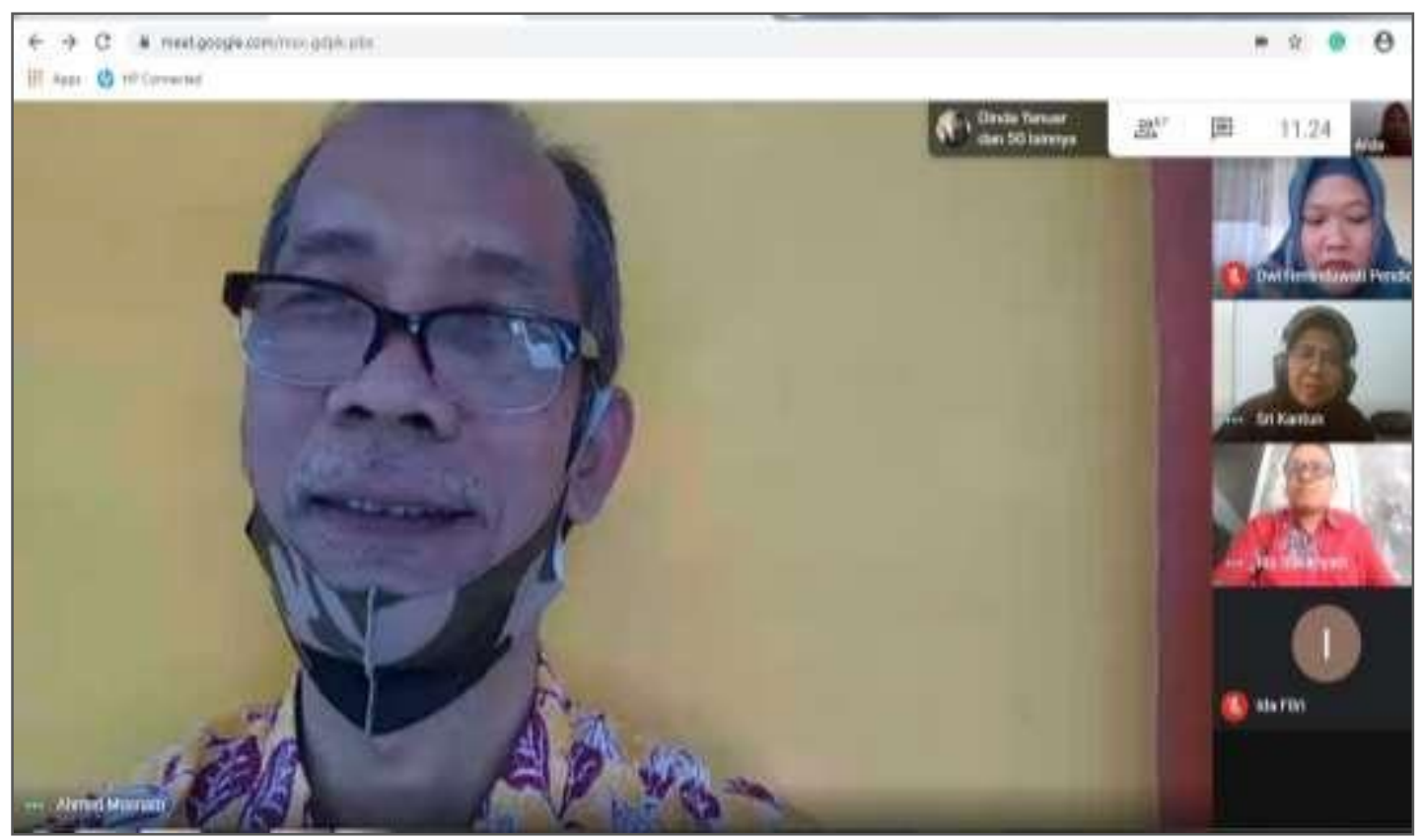

Gambar 8. Bapak Ahmad sedang bertanya kepada pemateri

\section{KESIMPULAN DAN SARAN}

Kegiatan Pengabdian Kepada Masyarakat dengan tema Merancang RPP Inovatif dalam Program Merdeka Belajar Pada MGMP IPS SMP Se-Kabupaten Jember memiliki dampak positif. Guru-guru IPS menjadi lebih paham tentang RPP Inovatif dalam merdeka belajar yang dicanangkan oleh Mendikbud. Kegiatan merancang RPP menjadi tidak berbelit-belit dan lebih efisien terhadap waktu. Selain itu, kesulitan pengaplikasian dalam kegiatan pembelajaran secara online bisa teratasi dengan adanya kegiatan ini. 
Merancang RPP Inovatif dalam Program Merdeka Belajar pada MGMP IPS SMP Se-Kabupaten Jember

Sri Kantun, Dwi Herlindawati, Lisana Oktavisanti M

Vol. 1, No. 2, Agustus 2021 hal. 137-146

DOI Artikel : $10.46306 /$ jub.v1i2.29

\section{UCAPAN TERIMA KASIH}

Ucapan terima kasih kami sampaikan kepada Bapak Dekan FKIP Universitas Jember, Ketua LP2M Universitas Jember yang telah memberikan ijin pelaksanaan kegiatan pengabdian masyarakat ini, Ketua MGMP IPS SMP Kabupaten Jember atas kerja sama ini, guru-guruanggota MGMP IPS SMP se Kabupaten atas kesediaan menjadi peserta kegiatan dan tim PKM yang sangat berkomitmen untuk kesuksesan kegiatan ini.

\section{DAFTAR PUSTAKA}

Jihad, A. (20I8). PENINGKATAN KOMPETENSI MAHASISWA UIN SUNAN GUNUNG DJATI BANDUNG DALAM MERANCANG RENCANA PELAKSANAAN PEMBELAJARAN (RPP) MATEMATIKA BERBASIS NILAI-NILAI ISLAM. Jurnal Analisa, 4(2), II6-I23. doi: I0.15575/ja.v4i2.3695

Nurvrita, A. S. (2020). OTONOMI PEMBELAJARAN BAHASA INGGRIS KAMPUS MERDEKA - MERDEKA BELAJAR. JPAK: Jurnal Pendidikan Agama Katolik, 20(2), 107-126. doi:10.34I50/jpak.v20i2.282

Probosiwi, P., \& Retnasari, L. (2020, November). Penyusunan RPP format terbaru mewujudkan merdeka belajar bagi guru sekolah dasar di PCM Prambanan. In PROSIDING SEMINAR NASIONAL HASIL PENGABDIAN KEPADA MASYARAKAT" STRATEGI MEMBANGUN KEMITRAAN DALAM PEMBERDAYAAN MASYARAKAT (No. 000, pp. 409-420). Lembaga Pengabdian Kepada Masyarakat, Universitas Ahmad Dahlan.

Rosmaliwarnis, R. (2019). Peningkatan Kompetensi Guru SMPN 5 Kecamatan Harau dalam Merancang Rencana Pelaksanaan Pembelajaran (RPP) Melalui Pendampingan Berkala. JUSIE (Jurnal Sosial Dan Ilmu Ekonomi), 2(0I), 72-79. doi:10.36665/jusie.v2i0I.II 7

Supriyadi, A. (202I). Pelatihan Strategi Menulis Proposal Hibah Kurikulum Merdeka Belajar-Kampus Merdeka. Jurnal Abdimas Prakasa Dakara, I(I), 25-28. doi: I0.37640/japd.vlil.937

Wambrauw, Y. L., Sonbait, L. Y., \& Mulyadi, M. (2020). Pengembangan Masyarakat Melalui KKN Merdeka Belajar Dalam Pengembangan Kemandirian di Tengah Pandemi Covid 19 Distrik Warmare Kabupaten Manokwari. IGKOJEI: Jurnal Pengabdian Masyarakat, I(I), 42-47. 
Merancang RPP Inovatif dalam Program Merdeka Belajar pada MGMP IPS SMP Se-Kabupaten Jember Sri Kantun, Dwi Herlindawati, Lisana Oktavisanti M

Vol. 1, No. 2, Agustus 2021 hal. 137-146

DOI Artikel : 10.46306/jub.v1i2.29 